\title{
Crisis management: the OSCE in the Republic of Moldova
}

\author{
Maria Raquel Sousa Freire
}

The O rganisation for Security and Cooperation in Europe (osCE) became involved in the Republic of M oldova at a time of much instability. This article analyses the organisation's multidimensional response to the problems in the country, especially efforts to achievea political settlement to the conflict between the central authorities in Chisinau and the Transdniestrian secessionists. In addition, it pays particular attention to the role of the other official mediators, Russia and U kraine, the significance of the withdrawal of Russian troops from Moldovan territory, and the promotion of reforms and democratisation. While assessing the osCE field mission as an instrument for crisis management, the paper underscores the need to view osCE activities in Moldova in a comprehensive way. So far, attempts to find a political settlement have proven unsuccessful, although developments in human rights, democratisation and military reform, for instance, may enhance confidence and build trust between the partiesbecoming fundamental pillars of a future agreement. Nevertheless, the prospects are not bright, and a political solution will require further commitment from external actors like Russia and U kraine.

Maria Raquel Sousa Freire is an assistant professor, Department of International Relations, Universidade Lusíada do Porto, Portugal. Her research focuses on the former Soviet space and the role of international organisations in conflict and security issues. 


\section{Introduction}

Theend of the Cold War presented an opportunity to establish a peaceful Europe in which the values of democracy and co-operation would prevail - a vision set out by the Conference on Security and Co-operation in Europe $(\mathrm{CSCE})^{1}$ in its 1990 Charter of Paris. ${ }^{2}$ Following the collapse of the Soviet Union and Yugoslavia, new states emerged and new understandings of security took shape, adding a socio-economic and cultural dimension to the traditional concept of politico-military security. At the same time, international organisations that focused on European security matters had to reformulate and adapt to the changed circumstances. The csce was not an exception.

Instead of withering away in the post-Cold War environment (as some observers expected), the csce enlarged, took on new tasks and adopted a more dynamic approach to the problems in its area. The Charter of Paris set a fresh course for the organisation, devising new principles and creating permanent institutions, which have since been refined on the basis of needs and experience. Specialised bodies, such as theForum for Security Co-operation (FSC), the Office for Democratic Institutions and Human Rights (oDiHR), the H igh Commissioner on National Minorities (нсNм) and the Representative on Freedom of the Media, were set up. N ew documents, including the 1994 Code of Conduct on Politico-M ilitary Aspects of Security, ${ }^{3}$ were signed. Regular meetings and assessment exercises have allowed activities to be co-ordinated and the implementation of osce commitments by participating states to be evaluated. ${ }^{4}$

New tasks in the areas of preventive diplomacy, crisis management and post-conflict rehabilitation, complementing action in the human, politico-military and economic spheres, have defined the organisation's post-Cold War agenda. The broad and integrated approaches developed by the organisation reflect the close linkages between all aspects of osce activity. In this way, the osce aims to play a part in raising awareness and building confidence. Nevertheless, the ideals for which it stands - a united and peaceful Europe with common values and shared principles- are still far from being realised. Within the newly independent republics of the former Soviet Union, for instance, economic, social, political and/or historical factors have contributed to an atmosphere of tension and have led to armed conflict in certain cases. Different political, economic, social, cultural and ethnic features shape the osce's view of conflict situations- reflected in the mandates and actions of its field missions. The functions of these deployments vary according to needs on 
the ground, although, in general, they all combine human rights, politics and economics (and military elements when applicable), including the provision of technical advice and assistance to the host country.

The osce is essentially playing a crisis-management role in the Republic of $\mathrm{M} \mathrm{ol}$ dova, involving the dispatch of good offices and the utilisation of mediation instruments- rather than enforcement mechanisms, such as sanctions or embargoes, or the use of force. As a mediator, the osce prepares and discusses proposals, suggests alternatives, and encourages and helps the parties to find a political solution to their problems. The organisation decided on 4 February 1993to establish a longterm mission to Moldova to facilitate'a lasting political settlement, on the basis of CsCE principles and commitments, of the conflict in the left bank D niester area of the Republic of Moldova.'. Two assignments are central to the mandate of the mission. First, it is to assist the parties in pursuing negotiations on a lasting political agreement, consolidating the independence and sovereignty of M oldova along with understanding about a special status for the breakaway region of Transdniestria. Second, it is to encourage the parties to pursue negotiations on the status and withdrawal of foreign troops. Additionally, the mandate allows the mission to gather information and to provide expertise in relation to, and advice on, the military situation, human and minority rights and the process of democratic transformation. Themission opened an office in the M oldovan capital of Chisinau on 25April 1993, and a branch office was set up in the capital of Transdniestria, Tiraspol, on BFebruary 1995, in accordance with an Understanding on theAct of the CsCE M ission in the Pridnestrovskaia Region of the Republic of M oldova. ${ }^{7}$

\section{Background to the conflict}

The Republic of Moldova, a territory of some 33,700 square kilometres, borders Ukraine in the north, south and east, and Romania in the west. The region between the Prut and Dniester Rivers was historically called Bessarabia(now the Republic of Moldova) and was annexed by the Russian Empire in 1812 After Russia's defeat in the 1854-56 Crimean War, Romania recovered the southern part of Bessarabia under the Paris Treaty of $30 \mathrm{M}$ arch $\mathbf{1 8 5 6}$. H owever, the territory was returned to Russia at the month-long Congress of Berlin in summer 1878. After a period under Tsarist control, Bessarabia was handed back to Romania in accordance with the Treaty of Brest-Litovsk signed between Russia and the central powers on 3M arch 1918. 
On 110 ctober 1924, the Soviet Union declared the U krainian region on the east bank of the Dniester River the Autonomous Soviet Socialist Republic of M oldavia. On 28June 1940, following the signing of the 1939 M olotov-Ribbentrop Pact, the Soviet Union demanded that Romania relinquish the regions of Bessarabia and northern Bukovina - territories that had been occupied by Soviet troops. In August, the Autonomous Soviet Socialist Republic of M oldavia was joined with the part of Bessarabia that had been annexed from Romania, becoming known on 2 August 1940 as the Soviet Socialist Republic of M oldavia. In July 1941 the Soviet Union again lost M oldavia to Romania (supported by German troops), excluding the area on the left bank of the D niester River. Soviet control was re-established in August 1944, after its forces entered Romania and occupied Bucharest-where a communist government was installed. The left bank area of the Dniester was thus never under Romanian control.

The present borders of Moldova were set in 1947with the formation of a new M oldavian Soviet Socialist Republic and the formal ceding of the area from Romania to the Soviet Union, in accordance with the Paris Peace Treaty of 1947. From that time, socialist policies were implemented in the territory, including the promotion of Russian and U krainian immigration, particularly to the industrial centres, and the imposition of Cyrillic script. As a result, Soviet power was institutionalised throughout the territory. ${ }^{8}$

By the late 1980s, political groups aiming to achieve national independence extended their influence in many of the former Soviet republics. In the Republic of M oldova, the Popular Front of M oldavia sought the re-introduction of Latin script in place of the Cyrillic alphabet, the adoption of Romanian as thestate language and the introduction of a new tricolour flag (like that of Romania), with the goal of defending the nationalist cause and breaking with Moscow. Reflecting these objectives, the Constitution of the M oldavian Soviet Socialist Republic was modified on 30 August 1989, making M oldavian the official state language (written in Latin script) and Russian the inter-ethnic language of communication. These amendments demanded that employees of the state administration and the holders of public office have a'necessary level' of knowledge of Moldavian and Russian - and Gagauz in areas with a Gagauz population ${ }^{9}$ - in order to fulfil their obligations. ${ }^{10}$ What a 'necessary level' meant was unclear, generating anxiety among those who did not speak the M oldavian language. ${ }^{11}$ At that time, almost every M oldavian speaker knew Russian, but not many Russian speakers knew Moldavian. Combined with the 
strengthening of the Popular Front, these developments crystallised Transdniestrian 73 fears regarding Moldavian unification with Romania.

Consequently, Transdniestria, which wanted closer ties with the Soviet Union, declared independence from the Republic of M oldova on 2September 1990. Three months later, the Second Extraordinary Session of People's Deputies of theDniester Area announced the establishment of the M oldovan Transdniestrian Republic, Pridnestrovskaia M oldavskaia Republika ( $\mathrm{PMR}$ ), following a referendum in which 97.7\% voted for autonomy ${ }^{12}$ - the central government did not recognise the statement. The laws of the Republic of M oldova were considered invalid in Transdniestria, and the secessionists sought to take control of the local-government institutions that were still under the authority of Chisinau.

M eanwhile, Moldova had declared itself an autonomous republic on 23June 1990, proclaiming the 1940 annexation by the Soviet Union illegal and reaffirming the supremacy of its constitution and national legislation. Formal independence was achieved on 27 August 1991 After years of authoritarian rule and operating in accordance with a centralised economy, the Republic of M oldova committed itself to developing democratic structures based on the rule of law and to asserting its sovereignty. On 8D ecember 1991, M ircea Snegur was elected the first president of M oldova with the support of the Popular Front. N evertheless, the demand for unification with Romania lost strength after the formation of a government of national unity in July 1992, as the consolidation of independence became the preferred strategy. O pinion polls organised in 1992and 1993and a referendum in 1994 revealed that, in fact, few people advocated unification. ${ }^{13}$ The primary goals became forging a new state and joining the community of European democratic states, particularly in view of Transdniestrian separatism.

\section{Eruption of armed conflict}

M oldova's post-independence political agenda heightened concern among Russian speakers, especially those settled on the left bank of the Dniester River. They feared theintroduction of political and economic reforms that would extinguish the socialist way of life. As noted above, Transdniestria had never been under Romanian control and its past was marked by Slavic influence. Moreover, Transdniestria, the most industrialised part of Moldova, held a strong strategic position in relation to the communications network and access to external markets. The region accounts 
for $\mathrm{Z} 2 \%$ of $\mathrm{M}$ oldovan territory and is home to $\mathrm{I} \%$ of its population (around 743,000 inhabitants ${ }^{14}$ ), yet it generates $35 \%$ of the republic's national income. ${ }^{15}$ As such, the majority of theTransdniestrian industrial élite was concerned about the potential loss of privileges and of socio-political prestige.

While Moldova committed itself to democratic principles and to the reformation of the old system, Transdniestria remained loyal to Soviet rule. Such positions necessitated a division of power in the country. N ot having the mechanisms to allow such a transformation to occur through peaceful and democratic means, however, conflict became inevitable.

Armed confrontation between M oldovan and Transdniestrian forces finally erupted in M arch 1992. The Transdniestrian leadership, led by Igor Smirnov, set up paramilitary structures and took control of the official institutions on the left bank. Chisinau tried to regain control of them through coercion, but Tiraspol responded by eliminating all law-enforcement organs still loyal to the Republic of M oldova. The latter's poorly equipped police and ill-trained army were easily overcome by PMR troops, which received hardware, support and instruction from the Russian 14th Army, stationed in Transdniestria. ${ }^{16} \mathrm{After}$ four months of intense fighting, Moldovan forces had to accept both their inferiority and Russian conditions for an end to the violence.

On 21July 1992, Moldova and Russia signed an agreement in M oscow on thePrinciples of a Peaceful Settlement of theArmed Conflict in Transdniestria. Theaccord established a ceasefire, defined a security zone along the Dniester River, demanded that human rights be respected, and provided for the deployment of a tripartite (Russian, M oldovan and Transdniestrian) peacekeeping force. ${ }^{17}$ This was under the supervision of the Trilateral Joint Military Command, subordinated to the Joint Control Commission (JCC) - set up in July 1992 with its headquarters in Bendery, Transdniestria. The functions of the Jcc include controlling the security zone, preventing violent incidents, and ensuring implementation of decisions regarding withdrawal and demilitarisation. In the event of a violation of the agreement on the Principles of a Peaceful Settlement of theArmed Conflict in Transdniestria, the Jcc is responsible for taking appropriate measures to restore law and order. ${ }^{18}$ In addition, the Russian 14th Army was to be neutral and negotiations were to take place on its status and on a timetable for withdrawal. The principles set forth in the agreement include respect for the Republic of M oldova's sovereignty and territorial integrity, and the need to establish a special status for the left bank. 


\section{Evolution of the two banks}

Since the signing of the agreement, M oldova and Transdniestria have evolved discretely, with separate economic, social, ideological, political and educational systems. The left bank maintains remnants of the Soviet system, has limited mechanisms to support a market economy, favours state ownership, and is oriented towards Russia and the Commonwealth of Independent States (cis). Despite its unrecognised status, the PMR has its own president, government and all the institutions of a functioning state (judicial, administrative and executive organs).

Hardly any economic reconstruction has occurred in Transdniestria in the past ten years. The left bank is dependent on Russia for raw materials and as a market for its produce. The search for new outlets has not been successful, as Transdniestrian goods are unable to compete in theWestern marketplace. Furthermore, the left bank does not receive any international assistance (because of its unrecognised status). 'In contrast to M oldova's capital, Chisinau, there are few billboards to be seen in Tiraspol: no hint of Pepsi or Playboy capitalism, instead there are ration cards for subsidised bread'.19

Yet the PMR has a well-organised military-industrial complex, including enterprises that manufacture armaments and factories that repair military equipment. Some 50,000 weapons and 40,000 tons of shells, rockets and bombs are produced and sold, constituting an important source of revenue. ${ }^{20}$ Moreover, the Transdniestrian leadership regularly pays salaries and pensions that are slightly above those offered in the Republic of M oldova, guaranteeing the population's loyalty to the separatist administration.

The right bank, meanwhile, has adhered to free market economics, privatisation, and democratic and Western principles. Nonetheless, M oldova is mainly an agricultural-based country and is highly dependent on Russia for energy and raw materials, as well as on markets in the cis (of which Moldova is a member). The republic suffered a recession from 1992 until 1996 and economic recovery has been slow. It benefits from international assistance, particularly through agreements negotiated with the International M onetary Fund (IMF) and the World Bank. However, these institutions have suspended loans on several occasions due to the unstable situation and Moldova's inability to comply with their demands.

Moldova is now ranked as one of the poorest countries in the world. ${ }^{21}$ The gulf between rich and poor is increasingly evident- only a few individuals engaged in parallel activities and shady business dealings have become prosperous. Corruption 
and the weak rule of law, aggravated by democratic inexperience and lack of understanding of free-market economics, do not contribute to a positive assessment. According to M oldovan President Vladimir Voronin: "The word "law" has become synonymous with "corruption", the word "reform" - with "stagnation", "poverty" and "trouble".'22

\section{A tortuous negotiating process}

Negotiations to find a lasting political settlement to the dispute have proceeded very slowly and have suffered many interruptions - reconciliation efforts have been hampered by mistrust, mutual accusations and uncompromising unilateral initiatives. A number of complex factors contribute to the intricate situation in M oldova, including the different political, economic and social orientations of the parties, the status of Transdniestria, the division of responsibilities between Tiraspol and Chisinau, the existence of large quantities of armaments and the presence of the Russian 14th Army. General consensus has been reached on the form of the accord, but not on the content. The belligerents have constantly committed themselves to dialogue and to further contact and concur that a solution must be found through peaceful means. Yet different interpretations of concepts and agreements have stifled thetalks. The status of Transdniestria remains the fundamental obstacle to a final settlement. Chisinau has agreed to grant autonomous status and wide powers to the PMR, but the M oldovan authorities are adverse to the idea of establishing a confederation, owing to the size of the territory and to the fact that it would be set up on a territorial basis, sincethere are no ethnic or cultural claims to the region. Transdniestria, however, believes that autonomy should be awarded via an 'inter-governmental' agreement between Chisinau and Tiraspol. A confederate solution would make the left bank a sovereign state, with parallel powers to those of M oldova. While the PMR does not intend to give up the powers that it has achieved to date, equalling those of a state, M oldova rejects the granting of fundamental powers to the left bank, including responsibility for security, defence and financial policy, since it does not recognise Transdniestria as a legal entity.

Another key issue is theextraction of Russian troops and equipment from Moldova. This has long been a source of disagreement between Chisinau and Tiraspol, and between M oldova and Russia. Chisinau sees the stationing of some 2,500 Russian troops and equipment on its territory as illegal occupation by a foreign force, a direct 
challengeto national unity (given thehelp provided by the 14th Army to the separatists), and as interference in its internal affairs, representing a continuing threat to its independence. ${ }^{23} \mathrm{O}$ the left bank, by contrast, Russian forces are perceived to be offering military, political and moral support- besides guaranteeing the separate status of Transdniestria, or at least providing a protective umbrella. The PMr believes $\frac{\text { 罂 }}{\frac{0}{4}}$ that the withdrawal of Russian troops would amount to 'a genuine betrayal of Russia's interests', ${ }^{24}$ and thus has little incentive to reach an agreement. ${ }^{25}$ Transdniestria claims ownership of the equipment and ammunition and has been trying to prevent its removal by requiring that any peace deal provide it with a status akin to that of a separatestate. The M oldovan authorities have repeatedly accused Transdniestria of uncooperative behaviour by refusing to accept military inspections, by engaging in illegal practices, and by devising numerous obstacles to the demilitarisation of the security zone. ${ }^{26}$

M oldova has asked for greater commitment from the Russian Federation on the withdrawal issue, stating that its passive attitude prevents real progress. The use of phrases like 'to postpone', 'to take notice of ' or 'to continue studying' does not providethelevel of (Russian) assurance that Moldova would like to see. ${ }^{27}$ Russia has linked the pulling out of the 14th Army from Transdniestria with a political settlement to the dispute. The aim of such a synchronised procedure is to eradicate fears on the left bank about a return to violence and to restore confidence. Russia has stressed that political, technical and social issues make the withdrawal difficult, particularly the transportation of equipment through Ukraine and the construction of houses for returned military personnel.

According to osce data, the size of the existing arsenal far exceeds the needs of the Russian contingent in the region. There is around 20 tons of military equipment for every Russian soldier in the PMR, a ratio described by the Deputy Chief of the osce mission, General Roman Hormoza, as 'unmatched in any other military contingent in the world'.28 At the osce Summit in Istanbul, Turkey, in November 1999, the organisation welcomed Russia's commitment to withdraw by the end of 2002, which it reaffirmed at the 1]July 2000 special session of the osce Permanent Council. The osce reiterated that an international assessment mission was ready to be dispatched to M oldova to ensure transparency in the demilitarisation of the security zone. ${ }^{29}$

M oldovan senior government sources point out that the absence of weapons and military personnel would facilitate negotiations-a view shared by the osce mission 
and U krainian mediators. Despite many obstacles to progress in the military field, including non-compliance with signed agreements and obstruction of on-site inspections, there has been some advancement. The Transdniestrian authorities, for example, have agreed, in principle, to grant observer access to their military bases in the security zone. International donors, such as France, Germany, H ungary, N etherlands, Poland, Romania, Sweden and the us, have offered expertise and technical assistance in regard to the destruction of matériel, and the osce has set up a fund to help the parties remove, destroy or adapt for industrial use their ammunition and equipment. The process may be accelerated by the fact that it could be an important source of income for Russia - its stockpile in the left bank is worth some $\$ 8$ billion. ${ }^{30}$ H owever, the commitment and goodwill of the parties remain fundamental. Forces on both sides are interested in maintaining the status quo. There are groups in the Republic of M oldova and on the left bank that reap economic and political benefits from the dispute, particularly as a result of illegal pursuits, including the smuggling of drugs, tobacco and weapons. These groups have substantial economic power, and thus wield considerable influence in relation to the peace process. ${ }^{31}$

Timeis working against a political settlement. The protracted nature of the negotiations has allowed two distinct positions within the same country to develop and to take root. A political solution, therefore, must make provision for the very different views of M oldova and Transdniestria. (This has proved a difficult task for the expert groups and the mediators.) M any observers saw the 2001parliamentary and presidential elections in Moldova as possibly offering a new opportunity for conflict resolution in the country. In general, the communist-oriented policies of the new government, its desire to integrate into the Russia-Belarus union and the increased importance attached to the Russian language could haveforged a closer relationship between the left and right banks. Despite an initial ly positive reception, though, the PMR leadership has distanced itself from the proposals presented by the Republic of Moldova, such as for new customs and tax stamps, and has refused to attend scheduled meetings with Voronin. Otherwise, 'the myth of Transdniestria as a fortress under siege would have crumbled',32 leading to a gradual erosion of the regime.

\section{The involvement of external states}

Russia, Ukraine and the osce mission are the three official mediators in the negotiations. They work together on documents and recommendations, participate 
in meetings and jointly sign agreements. Their presence prevents proposals being 79 put forward that contradict international norms or that may create tensions with other countries. Yet this generally co-operative approach has not proved sufficiently cohesive to influence the talks.

Notably, Romania (a neighbouring country) has not assumed the role of an official mediator. In early 1992, Romania participated with Russia, Ukraineand M oldovathe Quadripartite Commission - in attempts to mollify the growing hostility between M oldova and Transdniestria. These efforts included the adoption of a declaration defining a set of principles for a peaceful political solution, for the disarmament of irregular forces and for establishing a neutral status for the Russian 14th Army. With an increase in violence in June 1992, however, the Quadripartite Commission became inactive. In addition, the appeal for unification with Romania lost strength in Moldova, as demonstrated by statements regarding 'two independent states and one common culture, ${ }^{\prime 3}$ prompting Romania to distance itself from the diplomatic initiative.

Relations between M oldova and Romania have since improved with the signing of bilateral political and economic agreements. And Romania's desire to integrate into the European Union (Eu) has led to it becoming more involved in the quest for a solution to the Moldova-Transdniestria affair. Romania's key concerns relate to the effective withdrawal of military equipment from the left bank, and to the possible integration of Moldova into the Russia-Belarus union. ${ }^{34}$

For Russia, Ukraine and the osce, the solution to the conflict must encompass broad autonomous status for the region and some form of power sharing that is acceptable to both sides. Ukraine is in favour of restoring a unified socio-economic space and all ties between the left and right banks, which should be done according to the staggered terms of a peace deal and timetable for implementation. ${ }^{35}$ This gradual approach envisages reaching agreement on the less problematic issues (like social-policy questions) before the more delicate matters (such as security and defence and the status of Transdniestria) are tackled, with the aim of generating confidence and an atmosphere conducive to constructive dialogue. Decisions made by the parties should be implemented progressively, allowing structures and institutions to be adapted on both sides. U kraine has a direct interest in the stabilisation of the situation, since shipments of Russian military equipment flow, and illegal activities (trafficking of drugs and armaments, for instance) take place, across its border with the PMr. While officially committed to an early resolution of the con- 
flict, including the deployment of military observers in the security zone, Ukraine has welcomed Smirnov as an official visitor to the country and has shown interest in the industrial potential of the left bank. ${ }^{36} \mathrm{H}$ ence, it has adopted a soft posture during the negotiations.

M eanwhile, Russia has proved to bean inconsistent player in the peace process. It maintains links with the PMR and has demonstrated public support for the left-bank leadership on several occasions, but it continues to support the territorial integrity of Moldova. Such a contradictory position calls into question its role in the negotiations. Russia was accused of partiality during the armed confrontation of $\mathrm{M}$ archJune 1992, openly backing the secessionists. ${ }^{37}$ Chisinau claimed that Russia's stance goes against international regulations and the official commitment made by the Russian Federation in 1994 regarding the territorial integrity of M oldova. ${ }^{38}$ The fragile relationship between these two states is compounded by M oldovan references to the'occupying army', representing a'permanent source of conflict and a perpetual threat to [the] country's integrity and security'. ${ }^{39}$ M oscow's strategy is a twin response to the demands of those inside Russia who harbour nationalist tendencies and want to maintain influence in neighbouring countries, and to those who respect the principle of territorial integrity given the separatist challenges that Russia faces in places like Chechnya. ${ }^{40}$

Although the Russian authorities state that the establishment of order and stability are their primary goals in the mediation process, pronouncements by the president are often contradicted by the actions of the parliament- the Duma has even considered a motion to recognise Transdniestria. In several instances, the Duma has expressed its support for the independence of the PMR and has called for stronger ties between Russia and the breakaway region. The authorities on the left bank, of course, welcome these comments and appreciate the backing of parliamentary representatives. The M oldovan government has described such suggestions as 'unfriendly' and a violation of the norms and principles of international law. Furthermore, M oldova interpreted declarations of 'Transdniestria as primordial Russian land' as interference in its internal affairs and as an infringement on its sovereignty and territorial integrity. Chisinau emphasised, though, that it did not identify the Duma's posture with that of the president and the government.

Current Russian efforts to resolve the dispute should not be seen as the result of a profound shift in domestic policymaking. Russia has not applied any real political and economic pressure to compel the Transdniestrian leadership to sign a final peace 
agreement. Additionally, issues that might demand moreactive Russian participation in the negotiations, such as corruption in the Pмr and the illegal supply of weapons to Chechnya, do not seem to raise much concern in M oscow. This might be due to the strategic importance of Transdniestria - it is situated between Russia and territory acquired through the eastward expansion of the North Atlantic Treaty Organisation (NATO). Russian intervention with the aim of finally settling the conflict- via the application of effective political and economic pressure- would probably only be prompted by a reescalation of the violence. ${ }^{41}$

\section{Involvement of the oscE}

The other official mediator, the osce mission, has presented some draft documents and has assisted in establishing the framework for negotiations (it cannot impose ready-made solutions on the parties), initiating discussions on Transdniestria's status based on a territorial autonomy formula. ${ }^{42}$ Under this framework, it is proposed that the left bank be granted substantial self-rule in the political and cultural domains, including the creation of a special region with its own executive organisms, elective assembly and court, and that a single economic, social and legal spaceoperating in accordance with the principle of subsidiarity - be set up. Furthermore, the osce mission has stressed that pMr politicians must be proportionally represented in Moldova's parliament and in other key central bodies. In times of stalemate, the osCE mission has worked hard to promote understanding and has used diplomacy to try and persuade the parties to return to the negotiations - if not at the highest level, then at least at the expert level.

Lack of progress in the talks has hardened M oldova's view of the mission. For example, Chisinau has criticised the osce mission for its unsuccessful action in regard to the withdrawal of Russian troops and has demanded that it take a harder line on separatism. ${ }^{43}$ Transdniestria, for its part, sees the mission as a vehicle for internationalising its cause and for creating a link between the parties, for encouraging dialogue and for putting forward proposals. ${ }^{44} \mathrm{~N}$ evertheless, the PMR has condemned what it describes as the pro-M oldovan attitude of the mission - while the osce mission has been increasingly critical of Transdniestria's lack of co-operation during the talks. ${ }^{45} \mathrm{As}$ a result, the osce mission has been seeking to build confidence in the peace process. In particular, it appreciates that co-operation on military issues will enhance stability. 
Within the context of the Stability Pact for South Eastern Europe, ${ }^{46}$ Voronin (who is also Supreme Commander of theArmed Forces) has initiated a military-reform programme - to be implemented between 2000 and 2012 According to the M oldovan Deputy M inister of D efence, Gheorge Popa, this initiative will build trust in military policy and reinforce M oldova's claim that it wants to resolve the dispute by peaceful means. ${ }^{47}$ The programme aims to: reduce costs and increase the level of efficiency and technical training; create a legislative body responsible for framing the country's military policy; provide social protection to soldiers and their families; and encourage collaboration with militaries in other countries. (These measures complement signed agreements between M oldova and the left-bank leadership on cuts in the armed forces.) The Moldovan authorities know that the military-reform project makes a practical contribution to regional stability building, and is in line with the country's military pledges to the osce. Yet implementation of the programme is threatened by the socio-economic condition of the republic, especially the activities of the corrupt élite that receive substantial profits from illegal pursuits. And the programme does not apply to the PMR, despite many of the problems in Transdniestria having direct implications for M oldova, such as the illegal production, export and circulation of armaments.

Moldova is attempting to control the proliferation of armaments through inspection regimes and the observation of military activities. The annual exchange of military data within the osce framework (particularly at the fsc level) is intended to guarantee transparency and to foster dialogue between participating states on military matters. Transdniestria, however, does not consider itself bound by osce decisions, since its leadership did not participate in the negotiation of these documents - hampering their full implementation in M oldova. The PMR would liketo betreated as equal to the Republic of M oldova at osce meetings- the organisation views the left bank as an integral part of M oldova.

M eanwhile, the Code of Conduct on Politico-M ilitary Aspects of Security establishes principles regarding the role of armed forces in democratic societies and relations between states in the military field (connecting the politico-military and human dimensions of osce work). In this context, mission members have observed the withdrawal of some Russian troops and equipment, participated in inspections of the joint peacekeeping force, and have been pressing for the introduction of transparency measures, including unfettered access to bases on both banks and exchanges of military information on numbers of personnel and armoured vehicles. 
(In many instances, however, the Transdniestrian leadership has prevented on-site inspections or the release of data related to its military contingent and hardware. ${ }^{48}$ ) The aim is to minimise the concerns of the parties in relation to violations of agreed commitments and the pursuit of illegal activities, particularly in the security zone. Although Russia has offered assurances at osce meetings that it would withdraw from Transdniestria, the organisation has not been ableto exert real pressure on the country to comply with its promises. When policy decisions or the activities of osce field missions are inconsistent with Russian interests, the country adopts a non-cooperativestance. Russia does not intend to lose influence in the former Soviet space, particularly in M oldova. At the same time, though, it desires legitimacy and Western approval in relation to its actions in neighbouring republics, ${ }^{49}$ and it needs and has been benefiting from Western financial and economic assistance.

As well as the military aspect of osce work in Moldova, the human element also constitutes a critical area of activity. The mission offers advice, particularly on legal matters, to the Moldovan and Transdniestrian populations and to local representatives, and it provides input on those parts of a potential settlement that concern international commitments on human and minority rights. This is done through direct contact with local representatives, the organisation of seminars, or via private visits to osce offices. Abuses relate to the treatment of prisoners and to the general condition of jails on both sides of the river. M embers of the mission regularly visit these institutions, and have reported instances of torture, poor hygiene, epidemics and malnutrition. Serious violations have al so occurred in regard to the freedom of the press. The osce Representative on Freedom of the M edia, Freimut Duve, has reported extensive control of the media by political parties in M oldova and Transdniestria, as well as lack of funding for serious journalism. ${ }^{50}$

The organisation of seminars and workshops aims to consolidate civic principles and to build confidence between the two constituencies. One such gathering resulted in agreement on thelocal-history textbooks (covering the period of the conflict) that can be used in Moldovan and Transdniestrian schools. ${ }^{51}$ The osce mission has also been engaged in a Civic Diplomacy Project- in collaboration with the ODIHR, and with the support of the Council of Europe and the un. The objective of the programme is to increase human contact and to foster sustainable dialogue between civic groups from both sides of the river on matters of common concern. It also focuses on legislative review and reform, with regard to the provision of assistance to the Commission on the Reform of the Criminal Procedural Code. ${ }^{52}$ 
In addition, the osce mission has been monitoring developments relating to the prohibition of the use of Latin script in the $\mathrm{PMR}$, resulting from a decree that dates back to 9 September 1992. Several schools were closed as a consequence of the regulation, generating protests from Chisinau and from among the student population. A compromise was found in late 1994, when Transdniestria allowed non-state schools on the left bank to come under M oldovan jurisdiction, and thus to use Latin script. However, the PMR authorities have refused to grant licences on administrative grounds. The osce mission, while welcoming the 1994 accord, has described the Transdniestrian practice of prohibiting the teaching of M oldovan in Latin script as a violation of human rights..$^{53}$

Furthermore, the mission, with the backing of the oDIHR, has been supporting the work of non-governmental organisations (NGOS). Initiatives include promoting contacts between NGos from both banks of the Dniester River, and offering advice on legal and procedural matters related to the establishment and development of these organisations. Raising awareness among the population of the potential contribution of NGOS has been an arduous task, since they tend to be close to their respective government and their goals tend to be highly politicised. Lack of financial and/or personal resources also constrains their functioning.

The mission has also been involved in monitoring elections and referenda. According to the osce, these processes have, in general, been free and fair. There have been minor problems, such as inaccurate voter registers, but these have not been serious enough to call into question the results. In Transdniestria, however, neither candidates nor voters have been ableto participate in polls in an adequate manner, which the oDiHr attributes to lack of information and restrictions imposed by local authorities on freedom of movement. M oreover, none of the elections or referenda on the left bank has been monitored by the osce or another international organisation. ${ }^{54}$ Despite the efforts of the osce mission to encourage democratisation and respect for fundamental freedoms and human rights, many violations still take place and need to be addressed. Although the resolution of human issues is not sufficient to guarantee a final settlement of the dispute, it will contribute to the building of trust.

\section{Crisis management and the osce mission}

Any assessment of osce activity in M oldova must acknowledge the broad mandate of the mission. Its attempts to overcome the differences between the disputants have 
thus been multidimensional in character, ranging from confidence building and advising on legislative matters, to the promotion of human rights and the fostering of dial ogue to reinforce a sense of community. This approach reflects the mission's view that, when there is deadlock in the political arena, it does not mean that improvements in the human sphere cannot occur.

The osce mission has confronted numerous problems in respect to the political negotiations. It lacks the power of persuasion and is dependent on the political will of osce member states- which include one of the parties to the conflict and the other two mediators - to adopt any decisions. Consequently, no rigorous schedules or detailed measures have been agreed. Furthermore, the osce has no instruments to enforce implementation in the event of non-compliance, has a restricted budget and no military apparatus of its own. The mission has few 'carrots' or 'sticks' to reward or punish the parties. Despite its best efforts to overcome dissension and to encourage dialogue and confidence, the osce mission understands that the answer is not in its hands. As a mediator, it must combine its negotiation skills with recommendations (not always demonstrating clear commitment) emanating from osce headquarters in Vienna, Austria, the willingness of the parties to make concessions, and their desire to make progress in thetalks. In sum, a complex web of endogenous and exogenous factors affects the mediation activities of the osce mission.

The same issues apply to the mission's military mandate. In this sphere, though, the role of Russia is crucial, not only with regard to the withdrawal of its troops and equipment from the left bank, but also in relation to the political negotiations. The Russian Federation wields considerable economic and political influence over the parties. The osce, therefore, should remind the country of its obligations to the organisation. At the same time, the osce field mission should continue to implement its monitoring mandate, vital to the building of confidence between the disputants. M oreover, the fund established within the osce framework to support financially the extraction of foreign forces counters Russian claims that financial difficulties prevent it from completing the task. Senior Russian officials, however, continue to state that some troops should remain in the pmR to help implement a future agreement on the status of Transdniestria. ${ }^{55}$

In addition, the mission - which consists of eight members and has a limited budget- requires extra financial support from certain member states (like the Nordic countries and the us) or other international organisations (such as the $\mathrm{eu}$ ) in order to implement projects, particularly in thehuman and socio-economic fields. (Exam- 
ples include the repairing of infrastructure and the organisation of seminars.) Nonetheless, the mission has been able to promote democratisation in the republic, evidenced, for instance, by the fair-and-free electoral process in Moldova and the development of the NGo sector on the left and right banks (primarily in M oldova). However, M oldova and Transdniestria both have a long way to go before democratisation can be said to have taken root.

The increasing attention devoted to the M oldova-Transdniestria issue in the osce may raise awareness among the organisation's participating states and eventually lead to more directed and focused action. ${ }^{56}$ The involvement of many osce members ${ }^{57}$ in the voluntary fund set up to support the withdrawal of Russian troops and equipment from Moldova illustrates their commitment to finding a political solution to the conflict. M oreover, the final settlement might beframed in terms of the us-led fight against terrorism, since Transdniestria, neither internationally recognised nor bound by international norms (in its view), has been accused on several occasions of unlawfully producing and selling military equipment and of extending support to illegal groups, including illicit formations operating in Chechnya. ${ }^{58}$

Despite the lack of progress in the political negotiations, the two sides highlight accomplishments in terms of their willingness to engage in dialogue, the reduction in the number of peacekeeping troops and control posts in the security zone ${ }^{59}$ the reconstruction of shared infrastructure, such as bridges linking the two banks (repaired with eu funding), the signature of social and economic agreements, including in the energy sector, co-operation to combat crime, and, above all, the halting of armed conflict and the maintenance of peace. Such developments indicate that, although the prospects are still not bright, the parties are moving closer to a political agreement.

\section{Conclusion}

Events in the Republic of M oldova have proved too intricate to be solved easily. Lack of democratic experience, the quest for political influence and economic power, and the presence of foreign troops and armaments play a key part in this protracted dispute. The parties and the mediators believethat, despite the accomplishments noted above, it could still take a long time to resolve the disagreement. Chisinau regards the left bank as a subordinate, while Tiraspol sees M oldova and Transdniestria as equal partners. The current peaceful environment may further institutionalise 
such attitudes, which could lead to increased frustration and extremism on both

sides. The willingness of Moldova and the pmr to resolve the conflict, despite the presence of powerful pressure groups, must be clear and they must be prepared to make concessions. The economic factor may serve as a catalyst for change.

The achievement of a political settlement will not be sufficient to settle all of the belligerents' differences and problems, but it is a prerequisite for economic recovery, including the harmonisation of economic and financial systems, possibly involving the establishment of a central budget and unified currency. This would help to make the country attractive to international investors, and could lead to the restructuring of the social sector (through employment opportunities) and the creation of an equitable health and welfare system. Since many of the problems in Moldova and Transdniestria, such as the rise in crime, corruption and the illegal trafficking of human beings, armaments and drugs, stem from the economic crisis on both banks of the Dniester River, it is fundamental that the rule of law be strengthened and that an independent judiciary and democratic institutions and procedures be established. Moldova has made several amendments to its legislation so that it meets international standards and it has signed up to various international conventions, such as the European Convention on Human Rights, the Framework Convention for the Protection of National M inorities, and the European Convention on the Prevention of Torture ${ }^{60} \mathrm{H}$ owever, as stressed above, it still has a long way to go before one can claim that democratisation has taken hold. Transdniestria, as a non-recognised state, has not signed up to any such international convention. M oreover, its practices are based on totally different principles to those of M oldova. If a solution to the conflict implies integration of the two banks, M oldova and Transdniestria will have to make profound changes, since they are de facto two parallel states with duplicate structures. In the search for a solution, the involvement of external actors, particularly Russia and Ukraine, will be crucial. Russian may play a more decisive role, since it enjoys greater leverage to pressure the parties.

M oldova entered the twenty-first century as a partly free country, ${ }^{61}$ while Transdniestria remained tied to its Soviet past and quite inflexible as regards its future. The orientation of the new government of M oldova is still unclear, but whatever direction it chooses to go in, the osce mission will bethere to monitor and report. 


\section{Endnotes}

${ }^{1}$ The 1994 Budapest Summit voted to change the name of the csce to the Organisation for Security and Co-operation in Europe (oscE). The decision took effect on 1January 1995

${ }^{2} \mathrm{CsCE}$, Charter of Paris for a N ew Europe, 'A new era of democracy, peace and unity', 19-21November 1990, www.osce.org/docs/english/summit.htm.

${ }^{3}$ 'Code of Conduct on Politico-M ilitary Aspects of Security', Budapest Document 1994, Budapest Decisions, chapter Iv. See also Nooy, G. (ed.), Co-operative Security, The osce and its Code of Conduct, (Clingendael: Kluwer Law International/N etherlands Institute of International Relations, 1996).

${ }^{4}$ The csce welcomed all former Soviet republics as new participating states, as well as Central and East European countries that previously fell within the Soviet sphere. The organisation now consists of 55states.

${ }^{5}$ Csce 19th Committee of Senior O fficials M eeting, Journal no. 3, Annex 3, February 1993

${ }^{6}$ According to a 'M emorandum of Understanding on the csce Peace-Building Mission in M oldova between the Head of M ission and the Government of the Republic of Moldova', 7 M ay 1993, www. osce.org/publications/survey/survey04.htm.

7 'M emorandum of Understanding on the csce PeaceBuilding M ission in M oldova between the $\mathrm{Head}$ of Mission and the local authorities in the left bank Dniester areas of the Republic of M oldova', article vir, paragraphs 2-3, CsCE Communication 281, 2 February 1993.

${ }^{8}$ For more detail on M oldovan history, see, for example, Dima, N ., From M oldavia to M oldova: The SovietRomanian Territorial Dispute, (New York: Columbia University Press, 1991); King, C., The M oldovans, Romania, Russia, and the Politics of Culture (Stanford: Studies of Nationalities/H oover Institution Press, 2000).

${ }^{9}$ Gagauzia is a small area in the southern part of Moldova that is mainly inhabited by Turkic nationals. Along with Transdniestria, the Gagauz were worried about the future of their national and cultural status. In 1990, they demanded autonomy from the central authorities in Chisinau. Unlike the situation in the left bank, there was no armed conflict between the Gagauz separatists and $\mathrm{M} \mathrm{ol}$ dovan forces. An agreement on the region's special status was reached in December 1994, defining Gagauzia as part of M oldova, with a locally elected Popular Assembly, governor and executive committee. Chisinau sets the region's budget, which has generated tension from time to time. For further detail, see, for example, Chinn, J. and Roper, S., 'Territorial Autonomy in Gagauzia', Nationalities Papers, vol. 26, no. 1 M arch 1998, pp. 87-101: King, C., The Moldovans, Romania, Russia, and the Politics of Culture, op. cit., pp. 209-223

${ }^{10} \mathrm{CSCE}$, 'Report of the CSCE Human Dimension M ission to the Republic of M oldova', Office for Democratic Institutions and Human Rights (oDinR), Annex 3, 30 January-4February 1993.

${ }^{11}$ On 1 A pril 1994, following recommendations from the $\operatorname{CsCE}$, Moldova's new parliament suspended implementation of the language tests. 'Language regulations relaxed', Radio Free Europe/Radio Liberty (RFE/RL), 6 April 1994, www.rferl.org.

12 M elvin, N., Russians beyond Russia: The Politics of National Identity, (London: Pinter, Chatham H ouse Papers, 1995), p. 63

${ }^{13}$ According to a September 1992 opinion poll, $52 \%$ of respondents were against unification, $20 \%$ considered it a possibility, while only $8 \%$ considered unification inevitable. 'Human rights and democratisation in the newly independent states of the former Soviet Union: Implementation of the Helsinki Accords', Commission on Security and Co-operation in Europe, Washington, DC, January 1993, p. 85 In another poll conducted in 1992, the percentage of those favouring unification with Romania dropped from $\mathbf{2 2 \%}$ to $\mathbf{1 7 \%}$. By $\mathbf{1 9 9 3}$ only $8 \%$ favoured unification, while $6 \%$ opted for independence. In the non-binding referendum of $6 \mathrm{M}$ arch $1994,75 \%$ of M oldovans turned out and $95 \%$ of the votes were in favour of M oldovan independence from Romania. $R F E / R L$ Research Report, vol. 1 no. 26, 1992, p. 40; RFE/RL Research Report, vol. 2 no. 9, 1993, p. 16; 'Dramatic drop in support for Moldovan unification with Romania', BBC Summary of World Broadcasts, Soviet Union (swB/su) 2098 D/6, 12September 1994. See also M an, L., 'M oldavia, Past and Present, Why the Communists Won the Elections', Uncaptive M inds, vol. 7, no. 1 winter/spring 1994, p. 123

${ }^{14}$ In 1991 , the estimated population of Moldova was 4,3/3,000. See www.mldnet.com/moldova/populat.

${ }^{15}$ CsCe communication 281, 2February 1993, p. 14

${ }^{16}$ The Moldovan army was formed in M arch 1992 hence its inexperience and lack of preparedness to confront Transdniestrian troops backed by Russian forces. The latter were stationed in Transdniestria, a strategic area, particularly as regards access to the Balkans.

${ }^{17}$ CSCE communication 224, 29July 1992; 'Background paper on the Transdnestr conflict in M oldova', csce Conflict Prevention Centre, Vienna, Austria, $29 \mathrm{M}$ arch 1994, pp. 4-5 
${ }^{18}$ The peacekeeping force began operations on 29J uly 1992, comprising five Russian, three Moldovan and two Transdniestrian battalions. The Jcc was established following the signing of a bilateral agreement between the Republic of M oldova and the Russian Federation. It initially consisted of Russians, Moldovans and Transdniestrians (a total of 30 military observers, ten from each party). Ukraine and the osce contributed to Jcc monitoring activities from 1995 ' $U$ kraine to join peace process in Transdniestria', $R F E / R L, 30$ August 1995; 'U kraine joins Transdniestrian peace process', $R F E /$ $R L$, 11September 1995, www.rferl.org.

19 'M oldova: German paper decries conditions in Transdniestria', $R F E / R L, 300$ ctober 1996, www.rferl.org.

${ }^{20}$ See, for example, 'M oldovan foreign chief tells Russian officials to close Dniester channel supplying weapons to chechen rebels', M oldova News, 31)anuary 2001, www.azi.md/en.html.

${ }^{21}$ 'Europe: N owhere land', The Economist, 26June 1999, p. 61

22 'Inaugural Speech of His Excellency M r Vladimir Voronin, President of the Republic of M oldova', April 2001, www.ifes.md/elections/electionresults/ 2001presidential/speech/.

${ }^{23}$ See, for example, 'To speed up withdrawal', M oldova News, 18)anuary 2000, www.azi.md/en.html; 'Moldova: Russian envoy says M oscow to keep troops in Transdniestria', $R F E / R L$, 4 February 2002

24 'A Betrayal of the Interests of PMR and Russia', translation by British Helsinki Human Rights Group of an article that appeared in the PMR newspaper, Pridnistrovye, signed by the PMR M inister of State Security, M ajor-General Vadim Yurievich Antyufeev, September 2001

${ }^{25} \mathrm{~A}$ view shared by Crowther, W., 'The Politics of Democratisation in Post-Communist M oldova', in Dawisha, K. and Parrott, B. (eds.), Democratic Changes and Authoritarian Reactions in Russia, U kraine, Belarus and M oldova, (Cambridge: Cambridge University Press, 1997), p. 297; Graeger, N., Conflicts in the osce Area, (Oslo: International Peace Research Institute, 1995), p. 43, Olcott, M. ., 'Sovereignty and the "Near Abroad"', O rbis, vol. 39, no. 3, summer 1995, p. 363.

${ }^{26}$ For example, 'Transdniestria dragging the beginning of the security zone demilitarisation', M oldova News, 15September 1999, www.azi.md/en.html.

27 'Russian Jcc delegation showing passive attitude to Transdniestria conflict settlement work', M oldova News, 60 ctober 1999, www.azi.md/en.html.

28 ' OsCE "worried" by Russia's position over Transdniestrian military evacuation', $R F E / R L, 6$ January 2000 , www.rferl.org.
${ }^{29}$ Istanbul D ocument 1999, Istanbul Declaration, paragraph 19, www.osce.org/docs/english/summit.htm; osCE Newsletter, vol. viII, no. 6, June 2001, p. 20

30 'A new twist in the evolution of the Transnistrian conflict?', M oldova N ews, 4September 2001 www. azi.md/en.html.

${ }^{31}$ See Neukirch, K., 'Transdniestria and M oldova: Cold Peace at the Dniester', H elsinki M onitor, vol. $D$, no. 2, 2001, p. 132

32 ' $\mathrm{A}$ new twist in the evolution of the Transdniestrian conflict?', M oldova News, 4September 2001, www. azi.md/en.html.

33 'Why M oldova does not seek reunification with Romania', $R F E / R L$ Research Report, vol. 1 no. 5, 31 January 1992; 'M oldovan-Romanian relations are slow to develop', RFE/RL Research Report, vol. 1 no. 6, 26June 1992

${ }^{34}$ Bowers, S., D oss, M . and Ciobanu, V., 'Foreign Views of the Transdniestrian Conflict', Gagauzia and Transdniestria: The M oldovan Confederation Conundrum, (H arrisonburg, Virginia: The William R. Nelson Institute for Public Affairs, February 2001, available at www.jmu.edu.

${ }^{35}$ Author interview with Eugene Levitsky, Plenipotentiary Representative of the U krainian President, at the negotiations in the Republic of Moldova, Chisinau, June 1999.

${ }^{36}$ Bowers, S., D oss, M . and Ciobanu, V., 'Foreign Views of the Transdniestrian Conflict', op. cit.

37 'Yeltsin praises role played by 14th Russian Army in Dniester region', ввс swв/su 2075 D/2, 16August 1994. See also Eyal, J. and Smith, J., 'M oldova and the M oldovans', in Smith, G. (ed.), The Nationalities Question in the Post-Soviet States, (London: Longman, 1996), p. 241; H amm, M., 'Introduction' Nationalities Papers, vol. 26, no. 1 M arch 1998, p. 10

${ }^{38}$ CsCE 1994Budapest Summit, Budapest Decisions, chapter II, 'M oldova'.

39 United Nations document a/47/766/-s/24931-Annex, CSCE communication 281, 2February 1993, p. 8.

40 'Russian Foreign M inister condemning separatism', M oldova News, 10 ctober 1999, www.azi.md/en.

${ }^{41}$ Bowers, S., Doss, M . and Ciobanu, V., 'Foreign Views of the Transdniestrian Conflict', op. cit.

${ }^{42}$ osCE M ission Report 13 referenceno. 229, 12 November 1993, www.osce.org/moldova/documents/files/ Report13pdf.

${ }^{43}$ ' $\mathrm{M}$ oldovan speaker calls for a greater role of osce in Dniester settlement', M oldova News, 220 ctober 1999, www.azi.md/en.html.

44 'The situation in M oldova', CSCE Newsletter, vol. 1 no. 2 $M$ arch 1994, p. 2

${ }^{45}$ Ambassador William Hill commenting on the exit of the Transdniestrian delegation from the osCE 
Permanent Council meeting on DJuly 2000; 'Constitutional reform in Moldova has no dramatic bearing on negotiations over Transdniestria, says osce Head in Moldova', M oldova News, 21July 2000, www.azi.md/en.html.

${ }^{46}$ Resulting from a European Union (EU) proposal and under the auspices of the osce, the Stability Pact for South Eastern Europe is a political initiative 'to encourage and strengthen cooperation between the countries of South Eastern Europe as well as to streamline existing efforts for assisting South Eastern Europe's political, economic and security integration in Europe.' This encompasses three key areas: democratisation and human rights; economic reconstruction, development and cooperation; and security and defence. Moldova joined the Stability Pact on 28june 2001 For more details, see Special Coordinator of the Stability Pact for South Eastern Europe, 'Press Handout: The Stability Pact and Moldova', 6D December 2001 www.stabilitypact.org.

${ }^{47}$ 'The military reform that began with an essential reduction of the effective of the armed forces... will favour the increase of trust towards the military policy promoted by the Republic of M oldova and it also is convincing proof that Moldova will continue to observe the principle of solving the Transdniestrian conflict exclusively peacefully and it will have a positive impact over the solving of the problems in the localities from the eastern zone of the Republic of M oldova': Popa, G., 'The reform of the security sector', Stability Pact for South Eastern Europe Regional Conference, Bucharest, October 2001, www.ipp.md/Events/Pres GHPOPA.doc.

${ }^{48}$ For example, 'Talking points of the Secretary General to the Pc', 31M ay 2001 sec.GAL/79/01, 5J une 2001

${ }^{49}$ See Pursiainen, C., 'The Impact of International Security Regimes on Russia's Behaviour, the Case of the osce and Chechnya' in Hopf, T., Understandings of Russian Foreign Policy, (Penn State Press, 1999), pp. 109- 169.

${ }^{50}$ 'Report on Freedom of the M edia', osCE N ewsletter, vol. 6, no. 7, July 1999, pp. 18-19.

${ }^{51}$ Annual Report 2000 on oscE Activities, The Secretary General, sEC.Doc/5/00, 24 November 2000, p. 49

${ }^{52}$ Annual Report 2000 on Interaction between Organisations and Institutions in the oscE Area, The Secretary General, sEC.Doc/4/00, 24 November 2000, p. 72; оDIHR Annual Report 2001, Warsaw, December 2001, pp. 66-67.

${ }^{53}$ Author interview with Gottfried Hanne, Human Dimension Officer of the osce Mission to M oldova, Chisinau, June 1999. See also ‘Dniester school conflict intensifies', RFE/RL, 270 ctober 1994 'Parents accuse Dniester authorities of cultural genocide', $R F E / R L, 28$ M ay 1996, www.rferl.org; 'The single Romanian school from Tighina is activating in inhumane conditions', M oldova News, 14 December 1999, www.azi.md/en.html.

${ }^{54}$ See odihr and osce Parliamentary Assembly reports on elections and referenda.

55 'M oldova: Russian envoy says M oscow to keep troops in Transdniester', $R F E / R L$, 4 February 2002, www. rferl.org.

${ }^{56}$ See 'M oldova: are the Russian troops really leaving?', Hearing before the Commission on Security and Cooperation in Europe, One Hundred Seventh Congress First Session, 22 September 2001 cscE 107-15, www.csce.gov.

${ }^{57}$ Donor countries include France, Germany, Hungary Netherlands, Poland, Romania, Sweden and the us. 'M oldova: osce hopes Putin will act on arms withdrawal', $R F E / R L$, 7June 2000; 'osce considers funding Russian withdrawal from Moldova, said William Hill', RFE/RL, 19 November 1999, www. rferl.org; Istanbul D ocument 1999, Istanbul Declaration, paragraph 19 .

${ }^{58}$ See, for example, statement by Pamela Hyde Smith (Ambassador-nominee to Moldova), us Senate Committee on Foreign Relations, 25September 2001, 'Today the separatist regime in Transdniestria occupies one of the remaining Black $\mathrm{H}$ oles in Europe, a place where international standards of human rights, transparency, border controls, and cooperation with the international community are lacking'.

${ }^{59}$ By June 1999, there were 11control posts (down from $40)$ in the central and southern parts of the security zone and none in the north, where previously there were two.

${ }^{60} \mathrm{Co}$-operation and assistance programmes with countries of central and Eastern Europe, Council of Europe, Annual Report 1996, sG/Inf(97) 1 p. 43

${ }^{61}$ Karatnycky, A., 'A Century of Progress-The 1999 Freedom House Survey', J Jurnal of D emocracy, vol. 11 no. 1 J January 2000, p. 193 